\title{
IMPLEMENTASI LAYANAN KONSELING KELOMPOK UNTUK MENGATASI KEBIASAAN MEMBOLOS SISWA
}

\author{
Oleh: \\ Satriawan $^{1)}$, La Ode Muharam ${ }^{2)}$ \\ 1) 2) Jurusan Bimbingan dan Konseling \\ Fakultas Keguruan dan Ilmu Pendidikan, Universitas Halu Oleo \\ Email: ${ }^{1)}$ wakadiawawan@gmail.com ${ }^{2)}$ laodemuharam77@gmail.com
}

\begin{abstract}
ABSTRAK
Tujuan penelitian ini adalah untuk mengetahui implementasi layanan konseling kelompok dalam mengatasi kebiasaan membolos siswa di SMA Negeri 2 Watopute. Jenis penelitian adalah penelitian eksperimen dengan pendekatan pra-eksperimen. Subjek dalam penelitian ini adalah 6 orang siswa dari 58 siswa yang ada di SMA Negeri 2 Watopute. Data dikumpulkan dengan menggunakan angket kebiasaan membolos. Metode analisis data menggunakan analisis wilcoxon match pair test. Hasil penelitian menunjukkan bahwa layanan konseling kelompok dapat menurunkan kebiasaan membolos siswa SMA Negeri 2 Watopute, hal tersebut dapat dilihat dari sebelum perlakuan diberikan persentase siswa membolos yaitu 82,5\%, dan setelah pemberian perlakuan kebiasaan membolos siswa menurun menjadi59,51\%. Hasil uji hipotesis dengan menggunakan wilcoxon signed rank dengan taraf signifikan $\alpha=0,05$ diperoleh $\mathrm{P}=0,05$ diperoleh $\mathrm{P}_{\text {value }}=0,028 . \mathrm{P}_{\text {value }}<\alpha(0,028<0,05)$ dengan demikian $\mathrm{H}_{0}$ ditolak. Maka dapat disimpulkan bahwa layanan bimbingan kelompok mampu mengatasi kebiasaan membolos siswa.
\end{abstract}

Kata Kunci: Konseling Kelompok, Kebiasaan Membolos

IMPLEMENTATION OF GROUP COUNSELING SERVICES IN OVERCOMING STUDENTS' HABIT OF DITCHING

\begin{abstract}
The purpose of this study was to determine the Implementation of Group Counseling Services in overcoming the habit of ditching students' at SMA Negeri 2 Watopute. This is experimental research with the preexperimental approach. The subjects in this study were 6 students' from 58 students' at SMA Negeri 2 Watopute. The data were collected through truancy questionnaires. The data analysis method used Wilxocon match pair test analysis. The results showed that group counseling services could reduce Students' habit of ditching at SMA Negeri 2 Watopute. This can be seen from before the treatment given the percentage of students' ditching is $82,5 \%$, and after the treatment is given the habit of ditching students' decreased to $59,51 \%$. Based on the hypothesis test using the wilcoxon signed-rank test, it was found that it's significant was $\alpha=0,05$ with its $\mathrm{P}_{\text {value }}=0.028$. $\mathrm{P}_{\text {value }}<\alpha(0.028<0.05)$. The test result indicates that $\mathrm{H}_{\mathrm{o}}$ is rejected. It can be concluded that group guidance services can overcome students' habit of ditching.
\end{abstract}

Keywords: Group Counseling, Habit of Ditching 


\section{Pendahuluan}

Pendidikan merupakan salah satu sektor yang paling penting dalam pembangunan nasional. Pendidikan dijadikan andalan utama untuk berfungsi semaksimal mungkin dalam upaya meningkatkan kualitas hidup masyarakat Indonesia, dimana iman dan taqwa kepada Tuhan Yang Maha Esa menjadi sumber motivasi kehidupan segala bidang. Dictionary of education menyebutkan bahwa "pendidikan adalah proses dimana seseorang mengembangkan kemampuan sikap dan bentuk-bentuk tingkah laku lainnya di dalam masyarakat di mana ia hidup, proses sosial dimana orang dihadapkan pada pengaruh lingkungan yang terpilih dan terkontrol (khususnya yang datang dari sekolah), sehingga dia dapat memperoleh atau mengalami perkembangan kemampuan sosial dan kemampuan individu yang optimal

Melalui pendidikan baik formal ataupun informal, peserta didik memperoleh pengalaman dan peranannya sebagai seorang pelajar. Pada kenyataannya ada banyak kegiatan, tantangan, dan tuntutan yang dihadapi dan harus dijalankan oleh seorang peserta didik. Kegiatan, tantangan dan tuntutan tersebut akan semakin terasa besar bagi seorang pelajar apalagi ketika peserta didik memasuki tahapan usia sebagai seorang remaja khususnya pada jenjang pendidikan menengah.

Perkembangan peserta didik tidak lepas dari pengaruh lingkungan, baik fisik, psikis maupun sosial. Sifat yang melekat pada lingkungan adalah perubahan (Winkel, 2012). Perubahan yang terjadi dalam lingkungan dapat memengaruhi gaya hidup (life style). Apabila perubahan yang terjadi itu sulit diprediksi atau di luar jangkauan kemampuan, maka akan melahirkan kesenjangan perkembangan perilaku peserta didik, seperti terjadinya stagnasi perkembangan, masalah-masalah pribadi atau penyimpangan perilaku yang dikenal sebagai bentuk kenakalan remaja dalam hal ini salah satunya adalah kebiasaan membolos yang dilakukan oleh siswa.

Kebiasaan membolos adalah tindakan dimana seseorang tidak masuk kerja atau sekolah atau dapat dikatakan ia melarikan atau meloloskan diri yang sebenarnya pada waktu tersebut ia tidak sedang libur (Sarwono, 2002). Siswa yang membolos memiliki kemungkinan masalah atau kegagalan lebih besar sebagaimana dikemukakan Kartono (1991: 78) bahwa secara akademis siswa yang ke sekolah tetapi sering membolos akan menanggung resiko kegagalan dalam belajar.
Selain itu bagi siswa yang gemar membolos dapat terlibat dengan hal-hal yang cenderung merugikan, mulai dari pencandu narkotika, pengagum free sex dan mengidolakan tindak kekerasan atau dengan istilah lain adalah tawuran.

Berdasarkan wawancara saat studi awal yang peneliti lakukan di SMA Negeri 2 Watopute terdapat banyak kasus-kasus siswa membolos yang dilakukan siswa dan terjadi di sekolah sebagaimana keterangan dari Guru Bimbingan dan Konseling (BK) bahwa pada tahun ajaran 2018/ 2019 jumlah siswa yang membolos setiap harinya mencapai rata-rata 7 siswa, dalam satu minggu terdapat 42 siswa yang membolos dan dalam waktu satu bulan mencapai 170 siswa. Dari seluruh siswa yang membolos tersebut terdapat lima siswa yang memunyai persentase membolos paling tinggi.

Kebiasaan membolos ini perlu mendapat perhatian dari berbagai pihak. Bukan hanya guru piket saja melainkan seluruh komponen sekolah perlu dilibatkan termasuk perlu melibatkan orang tua siswa. Kebiasaan membolos ini sangat merugikan dan bahkan bisa saja menjadi sumber masalah baru. Apabila hal ini terus menerus dibiarkan berlalu maka yang bertanggung jawab atas semua ini bukan saja dari siswa itu sendiri melainkan dari pihak sekolah ataupun guru yang menjadi orang tua di sekolah juga akan ikut menanggungnya.

Kebiasaan membolos merupakan salah satu bentuk dari kenakalan siswa, jika tidak segera diselesaikan atau diatasi dapat menimbulkan dampak yang lebih parah. Banyak pihak yang dapat secara bersama mengatasi kebiasaan membolos ini, salah satunya pada bimbingan dan konseling yang memiliki tugas di antaranya adalah menangani kebiasaan membolos dangan berbagai upaya. Salah satu layanan dalam bimbingan dan konseling adalah dengan pemberian layanan konseling kelompok. Melalui layanan konseling kelompok seorang siswa akan memahami kondisi dirinya sendiri, lingkungannya, permasalahan yang dialami oleh individu, kekuatan dan kelemahan yang ada dalam dirinya, serta kemungkinan upaya untuk mengatasi segala masalah yang dihadapinya.

Kebiasaan membolos yang dilakukan siswa di SMA Negeri 2 Watopute yang selalu berulangulang yang dilakukan secara sendiri-sendiri maupun secara berkelompok, bila dilakukan secara terus menerus akan merugikan diri dan orang lain. Bagi diri sendiri akan menyebabkan siswa terlambat masuk sekolah yang dapat menyebabkan 
ia ketinggalan pelajaran hingga akhirnya menyebabkan nilai belajar rendah, selain itu perilaku membolos ini akan menjadi sebuah kebiasaan dalam diri siswa padahal itu merupakan kebiasaan buruk. Kebiasaan membolos juga akan merugikan orang lain seperti guru akan terhambat dalam pembelajaran, petugas piket yang selalu menangani masalah itu-itu saja dan yang paling nampak adalah terjadinya pelanggaran tata tertib sekolah yang akan memberikan kesan dan persepsi negatif dari masyarakat.

Implementasi layanan konseling kelompok diharapkan dapat membantu siswa merubah perilaku-perilaku yang tidak sesuai tersebut seperti kebiasaan membolos. Dengan adanya layanan konseling kelompok di sekolah ini bisa meminimalisir kebiasaan siswa yang sering membolos. Bukan dengan menghukum agar siswa jera dalam melakukan perbuataannya yang ternyata perilaku itu masih terus berulang hingga saat ini. Menghukum bukanlah cara yang baik untuk dilakukan saat ini karena tidak sesuai dengan perkembangan dunia pendidikan dan yang lebih penting adalah siswa yang berada pada masa remaja. Siswa yang baru menginjak remaja merupakan masa-masa dengan kondisi yang labil terutama dari sisi perkembangannya.

Layanan konseling kelompok adalah upaya memberikan bantuan kepada individu dalam suasana kelompok yang di dalam kelompok tersebut terdapat 4-8 anggota atau konseli yang berdiskusi dan memecahkan masalah. Pelaksanaannya dalam suatu tempat tertentu dengan didampingi seorang pembimbing atau lebih guna untuk membantu mengarahkan agar konseli nantinya akan memperoleh kemudahan dalam rangka perkembangan dan pertumbuhan. Adapun kelebihan layanan konseling kelompok ini adalah sebagai sarana dalam upaya membantu pengembangan dan optimalisasi dari potensi yang ada dalam individu yang utamanya berkaitan dengan pengembangan diri bidang sosial dan belajar serta mengentaskan permasalahan permasalahan kelompok yang dirasakan mengganggu kehidupan efektif sehari-harinya dengan memanfaatkan dinamika kelompok.

Layanan konseling kelompok merupakan layanan konseling yang dilakukan oleh seorang konselor terhadap klien dalam rangka pemecahan masalah pribadi klien dalam suasana kelompok dilaksanakan interaksi secara langsung antara klien dengan memanfaatkan dinamika kelompok dan konselor dalam rangka mambahas berbagai hal tentang masalah yang dialami klien (Prayitno, 2004:1).

Berdasarkan uraian permasalahan tersebut, maka peneliti memiliki minat untuk membantu siswa dan sekolah dalam menurunkan kebiasaan membolos yang selalu dilakukan siswa dengan memberikan perlakuan yaitu melalui layanan konseling kelompok. Pelaksanaan ini dalam bentuk penelitian dengan judul "Implementasi Layanan Konseling Kelompok untuk Mengatasi Kebiasaan Membolos Siswa". Tujuan dari penelitian ini, yaitu: untuk mengetahui apakah implementasi layanan konseling kelompok dapat menurunkan kebiasaan membolos siswa.

Sayid (2006: 347) menjelaskan kebiasaan adalah pengulangan sesuatu secara terus-menerus atau dalam sebagian besar waktu dengan cara yang sama dan tanpa hubungan akal atau dia adalah sesuatu yang tertanam di dalam jiwa dari hal-hal yang berulang kali terjadi dan diterima tabiat". Manusia bisa menyimpulkan bahwa manusia melakukan kebiasaan tanpa berpikir karena hal tersebut telah tertanam dalam jiwa manusia dan menjadi tabiat manusia.

Supriyo (2008: 113) menjelaskan bahwa membolos dapat diartikan sebagai anak yang tidak masuk sekolah dan anak yang meninggalkan sekolah sebelum usai tanpa izin. Selanjutnya, Kartono (2003: 21) menjelaskan perilaku membolos sekolah merupakan perilaku yang melanggar norma-norma sosial dan sebagai akibat dari proses pengondisian lingkungan yang buruk atau tidak baik.

Winarno (2007: 18) mengemukakan implementasi adalah tindakan-tindakan yang harus dilakukan oleh sekelompok individu yang telah ditunjuk untuk menyelesaikan suatu tujuan yang telah ditetapan sebelumnya. Latipun (2008: 178) menjelaskan konseling kelompok merupakan salah satu bentuk konseling yang memanfaatkan kelompok untuk membantu, memberikan umpan balik (feedback) dan pengalaman belajar.

Wibowo (2005: 35) menjelaskan bahwa kegiatan konseling kelompok merupakan hubungan antar pribadi yang menekankan pada proses berpikir secara sadar, perasaan-perasaan, dan perilaku-perilaku anggota untuk meningkatkan kesadaran akan pertumbuhan dan perkembangan individu yang sehat.

\section{Metode Penelitian}

Penelitian ini dilaksanakan di SMA Negeri

2 Watopute selama 4 bulan pada semester genap 
tahun ajaran 2018/ 2019. Jenis penelitian ini adalah penelitian eksperimen dengan pendekatan pra-eksperimental design. Perlakuan dalam penelitian ini adalah pemberian layanan konseling kelompok untuk mengatasi kebiasaan membolos siswa SMAN 2 Watopute.

Subjek penelitian adalah siswa yang memiliki jumlah frekuensi membolos paling banyak di SMA Negeri 2 Watopute. Siswa yang menjadi subjek penelitian berjumlah 6 orang. Siswa tersebut dipilih berdasarkan skor kebiasaan membolos siswa yang tinggi dan juga buku kasus guru BK di sekolah.

Data dalam penelitian ini dikumpulkan menggunakan angket kebiasaan membolos siswa yang disusun oleh peneliti. Angket kebiasaan membolos siswa digunakan untuk memeroleh data skor kebiasaan membolos pada siswa. Angket disajikan dengan menggunakan Skala Lirket dengan kriteria kategori jawaban SS: sangat sesuai, S: sesuai, TS: tidak sesuai dan STS: sangat tidak sesuai.

Dalam penelitian ini, peneliti menggunakan analisis deskriptif persentase untuk menganalisis data dengan cara mendeskripsikan data yang telah terkumpul sebagaimana adanya tanpa bermaksud membuat kesimpulan. Selanjutnya, data akan dianalisis menggunakan uji wilxocon match pairs test untuk mengetahui perbedaan signifikan pre test dan post test.

\section{Hasil Penelitian dan Pembahasan \\ Hasil Penelitian}

Analisis Deskriptif Skor Pre Test

Gambaran kebiasaan membolos siwa SMA Negeri 2 Watopute sebelum diberikan perlakuan (pre test) dapat diketahui berdasarkan hasil pengisian angket kebiasaan membolos siswa yang diberikan kepada siswa yang menjadi subjek penelitian. Hasil pre test secara keseluruhan dari angket kebiasaan membolos siswa sebelum diberikan layanan konseling kelompok, dapat dilihat pada tabel berikut ini.

\section{Tabel 1}

Skor Pre Test Kebiasaan Membolos Siswa

\begin{tabular}{|c|c|c|c|c|c|}
\hline No & Nama & $\begin{array}{c}\text { Jenis } \\
\text { kelamin } \\
\end{array}$ & $\begin{array}{c}\text { Interval } \\
\text { skor }\end{array}$ & Skor & Kriteria kategori \\
\hline 1 & $\mathrm{DP}$ & $\mathrm{L}$ & 174 & 84,1 & Sangat tinggi \\
\hline 2 & ONS & $\mathrm{P}$ & 159 & 76,8 & Tinggi \\
\hline 3 & $\mathrm{MH}$ & $\mathrm{L}$ & 166 & 80,2 & Tinggi \\
\hline 4 & $\mathrm{R}$ & $\mathrm{L}$ & 176 & 85,0 & Sangat tinggi \\
\hline 5 & LRS & $\mathrm{L}$ & 163 & 78,7 & Tinggi \\
\hline 6 & $\mathrm{Z}$ & $\mathrm{L}$ & 187 & 90,3 & Sangat tinggi \\
\hline \multicolumn{3}{|c|}{ Rata-rata } & 170,8 & 82,5 & Sangat tinggi \\
\hline
\end{tabular}

Berdasarkan Tabel 1 tersebut, terlihat bahwa kebiasaan membolos siwa SMAN 2 Watopute sebelum diberikan layanan (pre test) termasuk dalam kategori sangat tinggi. Hal ini dapat dilihat dari rata-rata persentase kebiasaan membolos siswa mencapai $82,5 \%$ dari 6 orang subjek penelitian.

\section{Analisis Deskriptif Skor Post Test}

Hasil post test (tes akhir) secara keseluruhan dari angket kebiasaan membolos setelah diberikan layanan konseling kelompok, dapat dilihat pada tabel berikut ini.

\section{Tabel 2}

Skor Post Test Kebiasaan Membolos Siswa

\begin{tabular}{|c|c|c|c|c|c|}
\hline No & Nama & $\begin{array}{c}\text { Jenis } \\
\text { kelamin }\end{array}$ & $\begin{array}{c}\text { Interval } \\
\text { skor } \\
\end{array}$ & Skor & Kriteria kategori \\
\hline 1 & DP & $\mathrm{L}$ & 120 & 58,0 & Rendah \\
\hline 2 & ONS & $\mathrm{P}$ & 117 & 56,5 & Rendah \\
\hline 3 & $\mathrm{MH}$ & $\mathrm{L}$ & 118 & 57,0 & Rendah \\
\hline 4 & $\mathrm{R}$ & $\mathrm{L}$ & 132 & 63,8 & Rendah \\
\hline 5 & LRS & $\mathrm{L}$ & 125 & 60,4 & Rendah \\
\hline 6 & $\mathrm{Z}$ & $\mathrm{L}$ & 127 & 61,4 & Rendah \\
\hline \multicolumn{3}{|c|}{ Rata-rata } & 123,2 & 59,51 & Rendah \\
\hline
\end{tabular}

Berdasarkan Tabel 2 di atas diketahui bahwa sebelum diberi perlakuan (pre pest) tingkat kebiasaan membolos siswa masuk dalam kategori sangat tinggi dengan skor persentase rata-rata $82,5 \%$. Sedangkan, setelah diberikan perlakuam (post test) tingkat kebiasaan membolos siswa berada pada ketegori rendah dengan skor persentase rata-rata $59,51 \%$. Hal tersebut menunjukan bahwa tingkat kebiasaan membolos siswa di SMA Negeri 2 Watopute mengalami penurunan sebesar $23,05 \%$.

\section{Analisis Statistik Inferensial}

Untuk mengetahui apakah pemberian layanan konseling kelompok dapat menurunkan kebiasaan membolos siswa sebelum dan setelah pemberian layanan konseling kelompok secara signifikan, digunakan uji wilcoxon dengan bantuan program aplikasi SPSS Version 17.0.

Berikut ini tabel hasil uji wilcoxon variabel layanan konseling kelompok dengan kecenderungan kebiasaan membolos siswa. 
Tabel 3

Hasil Uji Wilcoxon Match Pair

Test Statistics $^{\mathrm{b}}$

\begin{tabular}{|l|r|}
\hline & Post_test - Pre_test \\
\hline$Z$ & $-2.201^{\mathrm{a}}$ \\
Asymp. Sig. (2-tailed) & .028 \\
\hline
\end{tabular}

a. Based on positive ranks.

b. Wilcoxon Signed Ranks Test

Untuk mengetahui perbedaan kebiasaan membolos siswa sebelum dan setelah diberikan diberikan layanan konseling kelompok, dapat dilihat pada tabel wilcoxon tersebut. Diketahui nilai sig. < 0,05 pada taraf signifikan $5 \%$ atau $\alpha=0,05$. Berdasarkan tabel 4.3 nilai Asymp. Sig. (2-tailed) sebesar $0,028<0.05$, maka dapat disimpulkan bahwa terdapat perbedaan signifikan kebiasaan membolos siswa sebelum dan sesudah diberikan layanan konseling kelompok.

\section{Pembahasan}

Penelitian ini bertujuan untuk mengetahui apakah layanan konseling kelompok dapat menurunkan kebiasaan membolos siswa SMA Negeri 2 Watopute. Berdasarkan hasil analisis deskriptif persentase diketahui bahwa kebiasaan membolos siswa sebelum diberikan layanan konseling kelompok sebesar 170,8 atau dalam interval persentase $82,5 \%$ termasuk dalam kategori sangat tinggi. Setelah mendapatkan perlakuan berupa layanan konseling kelompok skor kebiasaan membolos siswa menurun menjadi 123,2 atau dalam interval sekitar 59,51\% termasuk dalam kategori rendah. Skor kebiasaan membolos siswa mengalami penurunan sebesar 47,6 $(23,05 \%)$ antara sebelum dan setelah diberikan layanan konseling kelompok.

Hasil uji Wilcoxon menggunakan taraf signifikansi $\alpha=0,05$, menunjukkan adanya perbedaan yang sinifikan pemberian layanan konseling kelompok terhadap kecenderungan kebiasaan membolos siswa kelas $\mathrm{X}$ karena nilai Asymp. Sig. (2-tailed) sebesar 0,028 lebih kecil dari pada nilai $\alpha=0,05(0,028<0.05)$. Berdasarkan hasil uji wilcoxon tersebut, dapat dikatakan bahwa layanan konseling kelompok dapat secara signifikan dalam menurunkan kebiasaan membolos siswa SMA Negeri 2 Watopute.

Kebiasaan membolos adalah aktiftas siswa yang pergi meninggalkan sekolah tanpa sepengetahuan pihak sekolah. Kebiasaan membolos dapat diartikan sebagai anak yang tidak masuk sekolah dan anak yang meninggalkan sekolah tanpa izin (Supriyo, 2008: 111). Membolos juga dapat diartikan sebagai perilaku siswa yang tidak masuk sekolah dengan alasan yang tidak tepat. Membolos merupakan satu bentuk kenakalan siswa yang jika tidak segera diselesaikan atau dicari solusinya akan menimbulkan dampak yang lebih parah. Oleh karena itu penanganan terhadap peserta didik yang suka membolos perlu menjadi perhatian bagi semua pihak.

Terdapat beberapa gejala dari kebiasaan siswa yang membolos sebagaimana dikemukakan oleh Prayitno dan Erman Amti (2004:61) bahwa ada beberapa gejala siswa membolos sebagai berikut:

1. Berhari-hari tidak masuk sekolah.

2. Tidak masuk sekolah tanpa izin.

3. Sering keluar pada jam pelajaran tertentu.

4. Tidak masuk kembali setelah minta izin.

5. Masuk sekolah berganti hari.

6. Mengajak teman-teman untuk keluar pada mata pelajaran yang tidak disenangi.

7. Minta izin keluar dengan berpura-pura sakit atau alasan lainnya.

8. Mengirimkan surat izin tidak masuk dengan alasan yang dibuat-buat.

Kebiasaan membolos ini menimbulkan banyak dampak negatif, sebagaimana dikemukakan oleh Supriyo (2008: 112) yang menjelaskan bahwa apabila orang tua tidak mengetahui dapat berakibat anak berkelompok dengan teman yang senasib dan membutuhkan kelompok/ grup yang menjurus ke hal-hal yang negatif seperti anak menjadi peminum, ganja, obatobat keras dan lain-lain. Akibat yang paling fatal adalah anak akan mengalami gangguan dalam perkembangannya dalam usaha untuk menemukan identitas dirinya. Akibat dari membolos menyebabkan banyak hal yang terjadi, di antaranya gagalnya peserta didik dalam mencapai prestasi dalam pembelajaran.

Konseling kelompok adalah suatu proses antar pribadi yang dinamis yang terpusat pada pemikiran dan perilaku yang disadari. Proses itu mengandung ciri-ciri terapeutik seperti pengungkapan pikiran dan perasaan secara leluasa, orentasi pada kenyataan, pembukaan diri mengenai perasaan-perasaan mendalam yang dialami, saling percaya, saling perhatian, saling pengertian dan saling mendukung (Shertzer \& Stone dalam 
Wibowo, 2005: 32). Dalam konseling kelompok berbagai permasalahan dapat diatasi dengan kepedulian anggota kelompok melalui pengembangan pemahaman, sikap, keyakinan dan perilaku konseli yang tepat dengan cara memanfaatkan suasana kelompok.

Konseling kelompok memiliki banyak kelebihan sebagaimana dijelaskan oleh Wibowo (2005: 41) yaitu kepraktisan, anggota kelompok dapat berlatih perilaku baru, terdapat terdapat kesempatan luas untuk berkomunikasi dengan teman-teman mengenai segala kebutuhan yang terfokus pada pengembangan pribadi, pencegahan dan pengentasan masalah yang dialami setiap anggota kelompok, anggota kelompok memiliki kesempatan untuk saling memberi bantuan, menerima bantuan dan berempati dengan tulus dalam konseling kelompok, konseling kelompok memberikan kesempatan yang luas agar anggota mempelajari keterampilan sosial baru, saling memotivasi, dapat secara langsung mencoba dan memraktikkan perilaku baru, dapat secara efektif mengembangkan kemampuan siswa dalam berinteraksi dengan orang lain, bertukar pikiran dan perasaan dan dapat mengembangkan pola hubungan dengan cara-cara yang produktif.

Hasil penelitian ini menunjukkan layanan konseling kelompok dapat mengatasi kebiasaan membolos pada siswa, hal ini sejalan dengan penelitian yang dilakukan olehWibowo (2013) yang hasilnya menunjukkan jika perilaku membolos pada subyek penelitian dapat dikurangi dan diatasi dengan konseling individu. Begitu pula penelitian yang dilakukan oleh Mahmudah (2013) yang hasilnya menunjukkan bahwa layanan konseling behavior dapat mengatasi masalah perilaku mambolos pada siswa.

Layanan konseling kelompok merupakan salah satu alternatif dalam menyelesaikan kebiasaan membolos pada siswa. Melalui konseling kelompok maka akan berkembang perasaan, pikiran, persepsi, wawasan dan sikap terarah pada tingkah laku khususnya dalam melakukan aktivitas sehari-hari dan juga terpecahkannya masalah siswa yang bersangkutan dan diperolehnya pemecahan masalah tersebut bagi siswa-siswa lain yang menjadi anggota kelompok.

\section{Kesimpulan Dan Saran \\ Kesimpulan}

Berdasarkan hasil penelitian dapat disimpulkan bahwa layanan konseling kelompok dapat mengatasi kebiasaan membolos siswa, hal ini ditunjukkan dengan hasil uji Wilxocon Match Pairs test diperoleh nilai $\mathrm{Z}$ sebesar $=-2,201 \mathrm{a}$, dengan Pvalue ( Asymp. Sig. (2-tailed) sebesar $0,028<0.05$, sehingga disimpulkan bahwa konseling kelompok dapat mengatasi masalah kebiasaan membolos siswa di SMA Negeri 2 Watopute.

\section{Saran}

Berdasarkan hasil penelitian yang telah dilakukan, maka saran yang dapat diberikan adalah:

1. Untuk siswa, layanan konseling kelompok dapat menurunkan kebiasaan membolos siswa, sehingga diharapkan siswa tidak ragu untuk mengikuti kegiatan tersebut dalam rangka menyelesaikan masalah-masalah yang dialaminya salah satunya adalah dalam menurunkan kebiasaan membolos.

2. Bagi guru BK, layanan konseling kelompok memiliki variasi layanan yang beragam, serta perlu dilaksanakan secara terprogram, sistematis dan berkelanjutan sehingga diharapkan kepada guru BK untuk dapat melaksanakan layanan bimbingan dan konseling setidaknya satu kali dalam seminggu agar supaya program layanan bimbingan dan konseling itu tidak fakum dalam melayani dan memberikan arahan kepada siswa.

3. Bagi sekolah, layanan bimbingan dan konseling secara umum dan layanan konseling kelompok khususnya telah terbukti dapat mengatasi kebiasaan membolos siswa, sehingga pihak sekolah diharapkan dapat memberikan jadwal tatap muka bagi guru BK dengan siswa, serta memberikan dukungan terhadap kegiatankegiatan BK.

4. Bagi peneliti selanjutnya, layanan BK merupakan layanan yang cocok untuk mangatasi dan memberikan arahan kepada siswa yang memiliki masalah di sekolahnya, jadi sebagai calon guru BK diharapkan kepada peneliti selanjutnya untuk lebih baik lagi dalam memberikan kegiatan layanan dalam BK.

\section{Daftar Pustaka}

Arikunto, Suharsimi (2014). Prosedur Penelitian Suatu Pendekatan Praktik

Fremont, W.P. (2003). School Refusal in Children and Adolescents. American Family Physician. 68(8), 1555-1560. 
Santoso, Joko. (2008). Strategi Belajar Mengajar. Surakarta: Fairuz Media Kartono.

Kartini, Kartono. (1991) Bimbingan Bagi Anak dan Remaja yang Bermasalah. Jakarta: Rajawali Press.

Latipun. (2005). Psikologi Konseling. Malang: UPT UMM.

Mahmudah. (2013). Pengaruh Layanan Konseling Kelompok dengan Menggunakan layanan Konseling Behavior. Jurnal Ilmiah Pendidikan Bimbingan dan Konseling, Vol. 4.

Mustaqim \& Wahib A. (2003). Psikologi Pendidikan. Jakarta: Rineka Cipta.

Pidarta, Made. (2013). Supevisi pendidikan Kontekstual. PT. Rieneka Cipta: Jakarta.

Prayitno. (2004). Layanan Bimbingan dan Konseling Kelompok. Padang: Ghalia Indonesia.

Prayitno dan Erman Amti (2008), Dasar-Dasar Bimbingan dan Konseling, Jakarta: Rineka Cipta.

Sarwono, J. (2002). Metode Penelitian Kuantitatif dan Kualitatif. Yogyakarta: Graha Ilmu.

Sayid, Muhammad. (2006). Pendidikan Remaja antara Islam dan Ilmu Jiwa. Jakarta: Gema Insani Press.

Sudjana, Nana dan Ibrahim. (2004). Penelitian dan Penilaian Pendidikan. Bandung: Sinar Baru Algensindo.

Sugiyono. (2016). Metode Penelitian Kuantitatif, Kualitatif dan $R \& D$. Bandung: PT Alfabeta.

Sukardi, Dewa Ketut dan Desak NilaKusmawati. (2016). Proses Bimbingan dan Konseling di Sekolah. Jakarta: Rineka Cipta.

Supriyo. 2008. Studi Kasus Bimbingan Konseling. Semarang: CV. Nieuw Setapak.

Suryosubroto. 2009. Proses Belajar Mengajar di Sekolah. Jakarta: PT Rineka Cipta.
Tohirin. (2007). Bimbingan dan Konseling di Sekolah dan Madrasah (Berbasis Integrasi). Jakarta: PT. Raja Grafindo Persada.

Undang-undang Nomor 20 Tahun 2003 Tentang Sistem Pendidikan Nasional.

Usman, Nurdin. (2002). Konteks Implementasi Berbasisi Kurikulum. Jakarta: PT. Raja Grafindo Persada.

Wibowo, Mungin Eddy. 2005. Konseling Kelompok Perkembangan. Semarang: Unnes Press.

Winarno, Budi. (2007). Kebijakan Publik Teori dan Proses. Media Presindo. Yogyakarta.

Winkel, WS \& MM. Sri Hastuti. (2012). Bimbingan Kelompok di Institusi Pendidikan. Jakarta: Rineka Cipta. 
